\title{
Racial disparities in COVID-19 pandemic cases, hospitalisations, and deaths: A systematic review and meta-analysis
}

\author{
William Mude ${ }^{1}$, Victor \\ M Oguoma², Tafadzwa \\ Nyanhanda ${ }^{3}$, Lillian \\ Mwanri ${ }^{4}$, Carolyne Njue ${ }^{5}$ \\ ${ }^{1}$ School of Health, Medical and \\ Applied Sciences, Central \\ Queensland University, Cairns, \\ Australia \\ ${ }^{2}$ Health Research Institute, \\ University of Canberra, Canberra, \\ Australia \\ ${ }^{3}$ School of Health, Medical and \\ Applied Sciences, Central \\ Queensland University, \\ Melbourne, Australia \\ ${ }^{4}$ College of Medicine and Public \\ Health, Flinders University, \\ Adelaide, Australia \\ ${ }^{5}$ The Australian Centre for \\ Public and Population Health \\ Research (ACPPHR), University \\ of Technology Sydney, Sydney, \\ Australia
}

\section{Correspondence to:}

William Mude; PhD, MPH, GradDipPharm, BSc (Hon) School of Health, Medical and Applied Sciences Central Queensland University, Cairns City Campus

42-52 Abbott Street \& Shields Street Cairns QLD 4870

Australia

w.mude@cqu.edu.au
Background People from racial minority groups in western countries experience disproportionate socioeconomic and structural determinants of health disadvantages. These disadvantages have led to inequalities and inequities in health care access and poorer health outcomes. We report disproportionate disparities in prevalence, hospitalisation, and deaths from COVID-19 by racial minority populations.

Methods We conducted a systematic literature search of relevant databases to identify studies reporting on prevalence, hospitalisations, and deaths from COVID-19 by race groups between 01 January 2020 - 15 April 2021. We grouped race categories into Blacks, Hispanics, Whites and Others. Random effects model using the method of DerSimonian and Laird were fitted, and forest plot with respective ratio estimates and 95\% confidence interval (CI) for each race category, and subgroup meta-regression analyses and the overall pooled ratio estimates for prevalence, hospitalisation and mortality rate were presented.

Results Blacks experienced significantly higher burden of COVID-19: prevalence ratio 1.79 (95\% confidence interval $(\mathrm{CI})=1.59-1.99)$, hospitalisation ratio $1.87(95 \%$ $\mathrm{CI}=1.69-2.04)$, mortality ratio $1.68(95 \% \mathrm{CI}=1.52-1.83)$, compared to Whites: prevalence ratio $0.70(95 \% \mathrm{CI}=0.0 .64-0.77)$, hospitalisation ratio $0.74(95 \%$ $\mathrm{CI}=0.65-0.82)$, mortality ratio $0.82(95 \% \mathrm{CI}=0.78-0.87)$. Also, Hispanics experienced a higher burden: prevalence ratio $1.78(95 \% \mathrm{CI}=1.63-1.94)$, hospitalisation ratio $1.32(95 \% \mathrm{CI}=1.08-1.55)$, mortality ratio $0.94(95 \% \mathrm{CI}=0.84-1.04)$ compared to Whites. A higher burden was also observed for Other race groups: prevalence ratio 1.43 (95\% CI=1.19-1.67), hospitalisation ratio 1.12 (95\% CI=0.89-1.35), mortality ratio $1.06(95 \% \mathrm{CI}=0.89-1.23)$ compared to Whites. The disproportionate burden among Blacks and Hispanics remained following correction for publication bias.

Conclusions Blacks and Hispanics have been disproportionately affected by COVID-19. This is deeply concerning and highlights the systemically entrenched disadvantages (social, economic, and political) experienced by racial minorities in western countries; and this study underscores the need to address inequities in these communities to improve overall health outcomes.

In December 2019, a new pneumonia-like infection with varying symptoms, ranging from mild to severe shortness of breath, emerged from Wuhan, China [1]. A World Health Organisation (WHO) investigation designated the infection as a 2019 novel coronavirus and was subsequently named COVID-19 [2]. The infection quickly spread throughout the world; at the time of writing, the source has not yet been determined. It was declared a public health emergency of international concern by WHO in January 
2020 and became a pandemic in March [3,4]. Transmission occurs through air droplets, and no proven cure had existed against the virus. As of 24 May 2021 at 2:50 pm Central European Summer Time (CEST), there have been 166860081 confirmed COVID-19 infection cases and 3459996 related deaths worldwide and rising [5] .

Available evidence suggests that medical comorbidities, obesity, diabetes, old age, and being a male are risk factors for COVID-19 [6,7]. However, in countries where data has been reported for race, the data shows that the burdens of COVID-19 are disproportionately high among racial minority groups $[6,8]$. For example, in the United Kingdom, the United States of America, and Brazil, high cases of COVID-19 are reported in people from racial minority groups [9-12]. The reports show that in the United Kingdom and the United States of America, 35\% and 33\% of COVID-19 patients, respectively, are from racial minority populations $[7,10]$, although these populations make much lower proportions of the total population. Some experts have claimed these disproportionately high burdens of COVID-19 are a result of health disparities and entrenched inequities experienced by minority communities [13]. However, conflicting findings relating to the reported burden of COVID-19 by racial groups have shown different rates. Some reports have claimed that White populations have higher mortality than Blacks, Asian, and Minority Ethnic (BAME) groups, while others showed that BAME groups have higher cases or no differences [14-16]. A recently published systematic review by Pan and colleagues [17] suggests that Blacks have a high risk of acquiring COVID-19 infection and worse clinical outcomes than Whites. However, the systematic review conducted by Pan and colleagues [17] did not run a meta-analysis and only summarised finding from each of the studies without synthesising them to highlight the extent of the issue.

In this article, we report our systematic review and meta-analysis of the literature on the burden of COVID-19 by race. We assessed the disparity of COVID-19 prevalence, hospitalisation and mortality ratios among Blacks, Hispanics, Whites, and Other race groups. This review provides vital information on the burdens of COVID-19 among the selected race group and will help support policies that address health inequities.

\section{METHODS}

\section{Search strategy}

Our search strategy was guided by the PRISMA statement [18]. We conducted the systematic search strategy in the following databases and conference proceedings: CINAHL Complete, Medline, Web of Science (Science Citation Index Expanded (SCI-EXPANDED), Social Sciences Citation Index (SSCI), Arts \& Humanities Citation Index (A\&HCI), Conference Proceedings Citation Index- Science (CPCI-S), Conference Proceedings Citation Index- Social Science \& Humanities (CPCI-SSH), and Emerging Sources Citation Index (ESCI)) for peer-reviewed papers published between 1 January 2020 - 15 April 2021. We searched these databases and conference proceedings using the search terms: TI(prevalence OR incidence OR burden* OR rate* OR death* OR Mortali*) AND (COVID-19 OR 2019 novel coronavirus disease OR COVID19 OR COVID-19 pandemic OR SARS-CoV-2 infection OR COVID-19 virus disease OR 2019 novel coronavirus infection OR 2019-nCoV infection OR coronavirus disease 2019 OR coronavirus disease-19 OR 2019-nCoV disease OR COVID-19 virus infection) AND (people of colo* OR minor* OR immigrant* OR African American OR Hispanics OR black* OR emigrant* OR ethnic). We also searched grey literature and government websites for COVID-19 data by race.

\section{Outcomes}

The primary outcomes assessed were COVID-19 prevalence, hospitalisations, and deaths by the following selected race categories: Blacks, Hispanics, Whites, and Other race groups. Blacks were defined as people with African ancestral origins who self-identify or are identified as Black, African or Afro-Caribbean $[19,20]$. Whites were described as people with European ancestral origins who identify or are identified as White non-Hispanic [20]. Hispanics were defined as people of Spanish speaking backgrounds from Central and South America who identify or are identified by others as Hispanic or Latino. Other race groups were defined as race groups not identified as Whites, Hispanics or Blacks (Asians, Indigenous, mixed-race, and unknown). Few COVID-19 studies have categorised Asians as a separate racial group when examining COVID-19 outcomes by race. Because of this, we have grouped Asian in "Other race groups".

\section{Screening and appraisal}

The lead author, the third co-author and the last co-author conducted the search and screening process separately, identifying studies by titles and abstracts. Studies that reported race data on prevalence or deaths or hospitalisations were included in this study. Studies were excluded if they were commentaries, letters, reviews, 


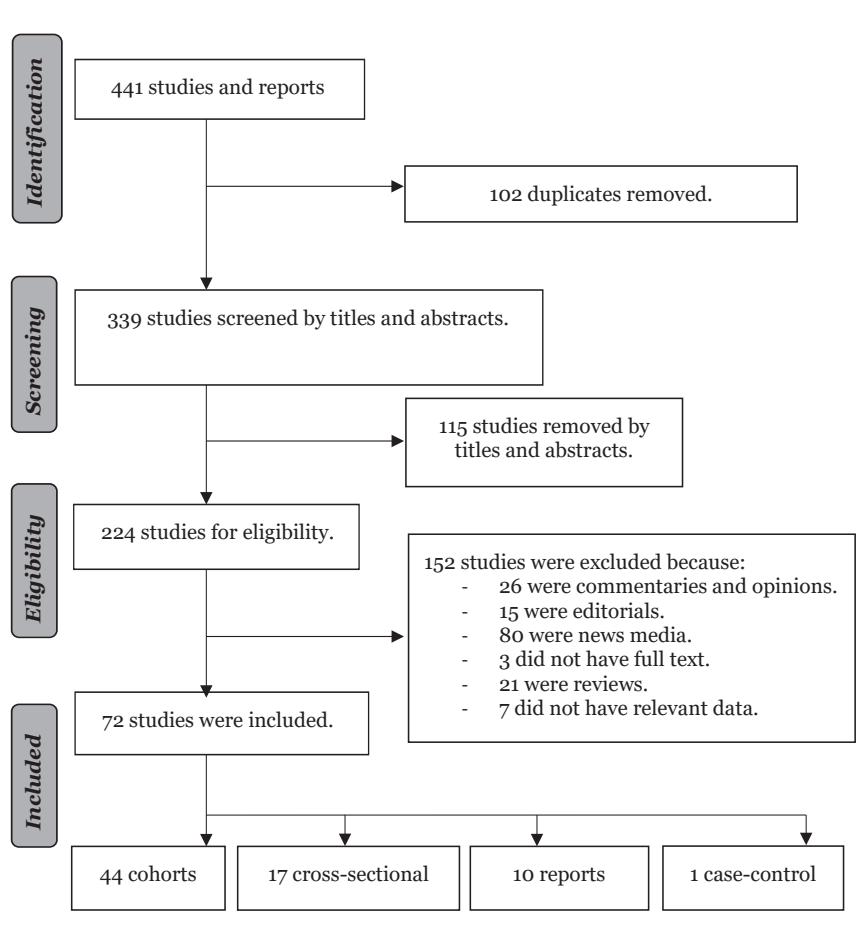

Figure 1. Flow diagram of studies included in the review. and opinions. At the same time, studies that reported prevalence, deaths, and hospitalisation for other health conditions were excluded. After removing the duplicates, studies were screened by titles, abstracts and read in full. Studies that met the inclusion criteria (Figure 1) were appraised for quality using the JBI quality appraisal for systematic literature reviews [21].

\section{Data extraction and meta-analysis}

We independently extracted information from studies that met the inclusion criteria. Information on the author, year of publication, country, study design, race, population proportion, samples, cases, prevalence, deaths, and hospitalisation was extracted, where appropriate. We separated the studies into four different race groups: Blacks, Hispanics, Whites, and Other race groups (Asians, Indigenous, mixedrace, and others).

We calculated the expected number of cases, hospitalisations, and deaths for each study, where appropriate. We used the expected number of cases, hospitalisations, and deaths to calculate the prevalence, hospitalisation, and mortality rate ratios weighted by the population of each race group. Where population proportion for race category was not provided, we used respective country census data (USA

[22] and UK [23]) to determine each race proportion to establish weighted prevalence ratio, hospitalisation ratio, and mortality rate.

We assumed that the probability for the occurrence of the expected cases, hospitalisations and deaths was the same as the probabilities for the occurrence of the observed cases, hospitalisations, and deaths in the absence of any changes in the rate of infectivity and the risk of exposure. We also assumed that all members of the population were at risk of infection, hospitalisations, and deaths from COVID-19 because no vaccination had existed at the time and that the pattern of the outbreak was random. That is, people randomly took up testing for COVID-19 from drive-by testing centres and hospitals, and therefore the reported samples were representative of the population group.

We calculated 95\% confidence intervals (CI) using both the exact Poisson distribution approach for observed and expected counts $<100$ and the approach for observed and expected counts $>100$ [24]. Random effects model using DerSimonian and Laird's methods were fitted, and forest plot with respective ratio estimates and 95\% CI were presented for each race category in subgroup analyses and the overall pooled ratio estimates for prevalence, hospitalisation and mortality. The -statistic was used to test the overall effect with statistical significance set at $\alpha \leq 0.005$ Heterogeneity between studies was assessed using the $I^{2}$ statistic. Nonparametric trimand-fill analysis was used to assess for publication bias [25,26]. Multivariable meta-regression was performed to explore heterogeneity resulting from the relationship between study effect sizes and race, country, year, and study design. The metan Stata module in Stata 16.1 MP (StataCorp, College Station, TX, USA) was used to conduct the meta-analysis [27].

\section{RESULTS}

\section{Studies}

We included 72 studies that reported at least observed cases, hospitalisations, or deaths from COVID-19. The included studies and the period covered by each study are provided in Table S1 in the Online Supplementary Document. Fifty-four studies (75.0\%) were from the United States of America, 13 (18.1\%) from the United Kingdom, and five (6.9\%) from Brazil. Forty-four studies were cohorts (61.1\%), 10 reports (13.9\%), 17 cross-sectional (23.6\%) and one case-control (1.4\%). Twelve studies (16.2\%) reported the observed cases, hospitalisations, and deaths [28-40]. Ten studies (13.5\%) reported observed hospitalisations and deaths [41-50], and eight studies (12.2\%) reported cases and deaths [34,51-58]. Two studies (2.8\%) reported observed cases and hospitalisations [59,60]. Seventeen studies (22.6\%) reported observed cases only [61-77]. Twelve studies (16.2\%) reported hospitalisations [78-88], and 11 (14.9\%) reported deaths only [12,89-98]. 


\section{COVID-19 prevalence ratio}

Thirty-nine studies (54.2\%) (22 cohorts [28-32,34,36,40,52-57,59,62,63,66,67,73-75], ten cross-sectional $[35,51,58,61,64,65,68-70,72]$, six reports $[33,38,39,71,76,77]$, and one case-control study [60]) had data to calculate the standardised prevalence ratio of COVID-19 for the identified race categories in the general community. The pooled prevalence ratio for Blacks was $1.79\left(95 \% \mathrm{CI}=1.59,1.99 ; I^{2}=99.9 \%, P<0.001\right)$ (Figure 2, Panel A), Hispanics 1.78 (95\% CI=1.63, 1.94; $I^{2}=99.9 \%, P<0.001$ ) (Figure 2, Panel B), Other race groups 1.43 (95\% CI = 1.19, 1.67; $I^{2}=100.0 \%, P<0.001$ ) (Figure 2, Panel C), and Whites 0.70 (95\% CI=0.64, 0.77; $\left.I^{2}=99.9 \%, P<0.001\right)$ (Figure 2, Panel D).

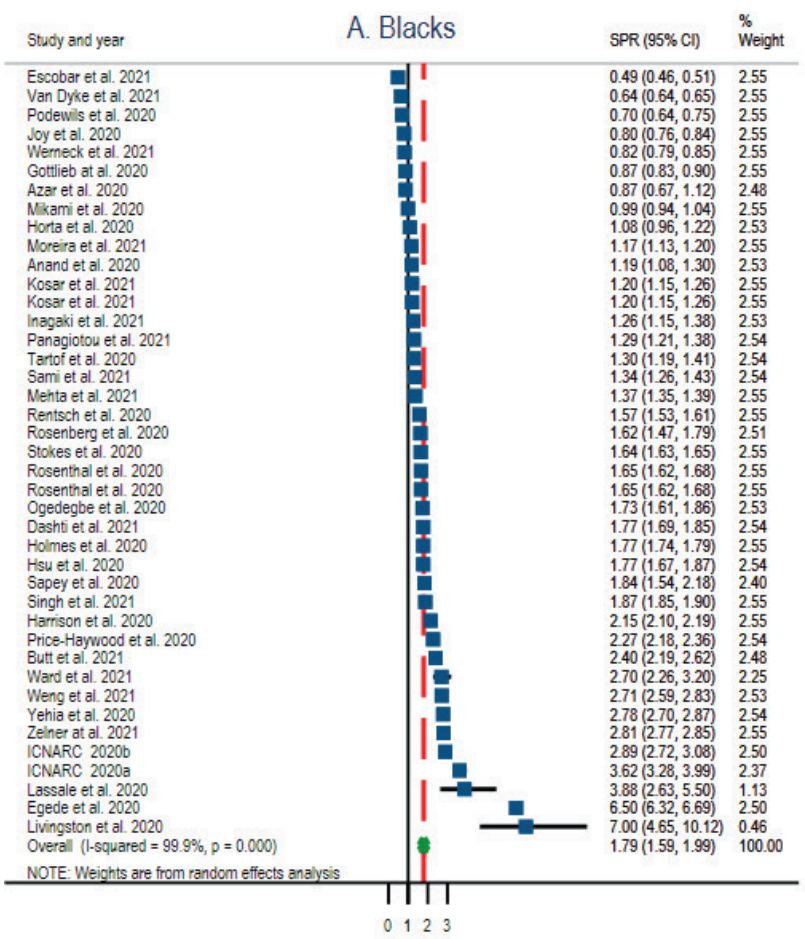

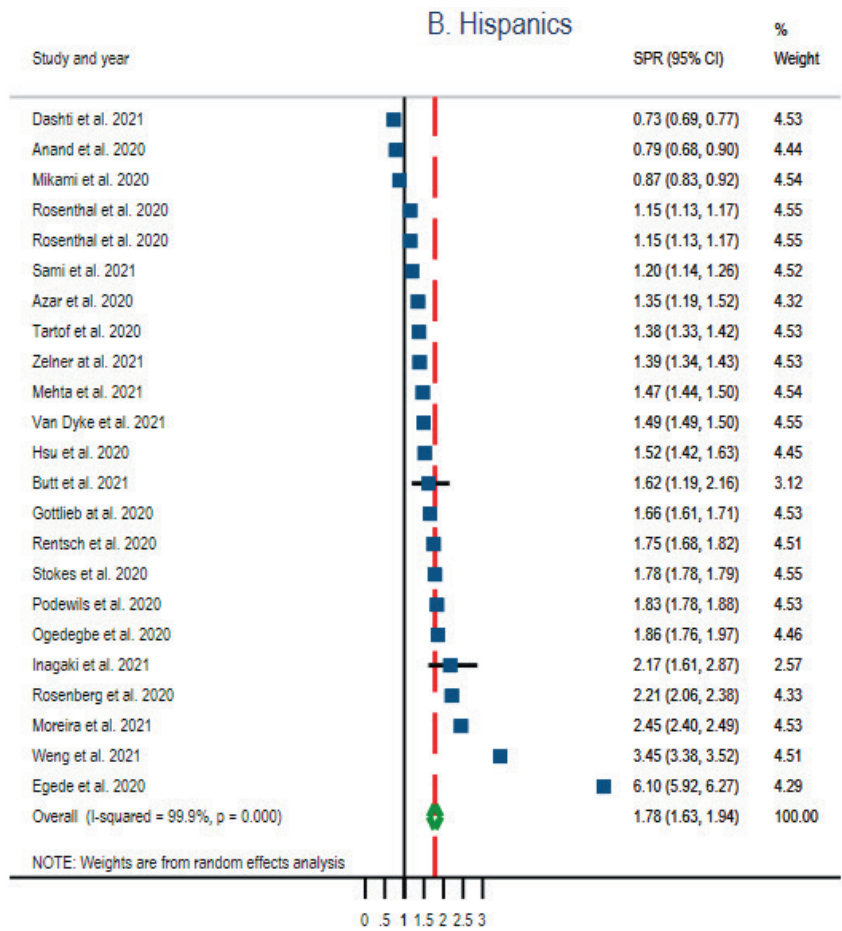

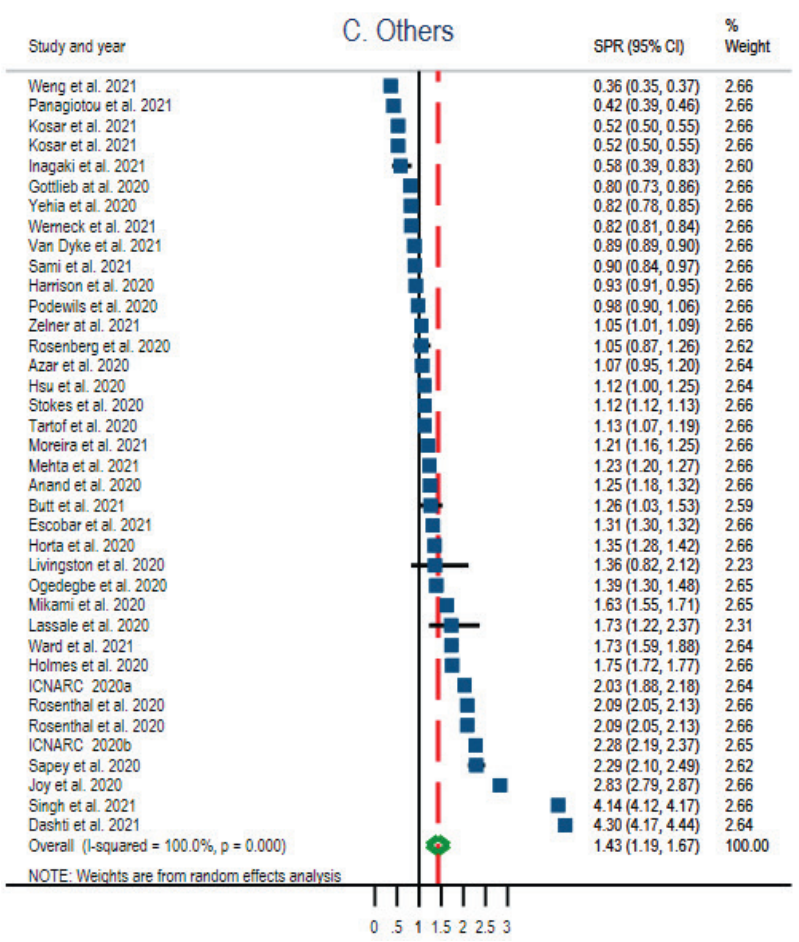

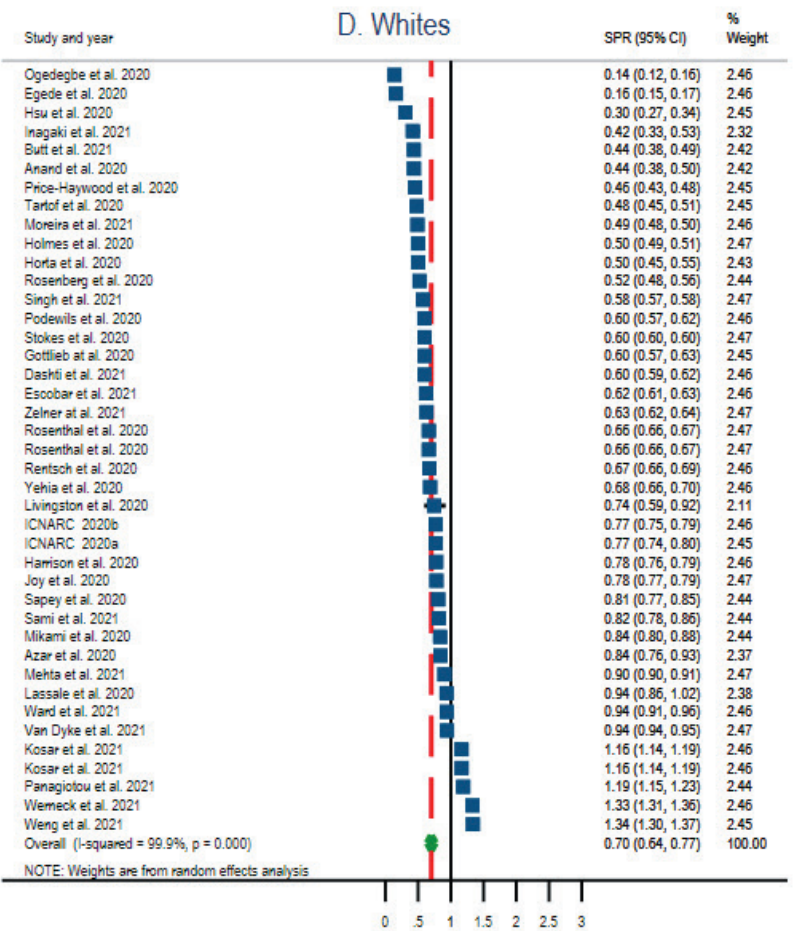

Figure 2. Standardised prevalence ratio (SPR) Forest Plots of COVID-19 by selected race groups. Panel A: Blacks. Panel B: Hispanics. Panel C: Other race groups. Panel D: Whites. 


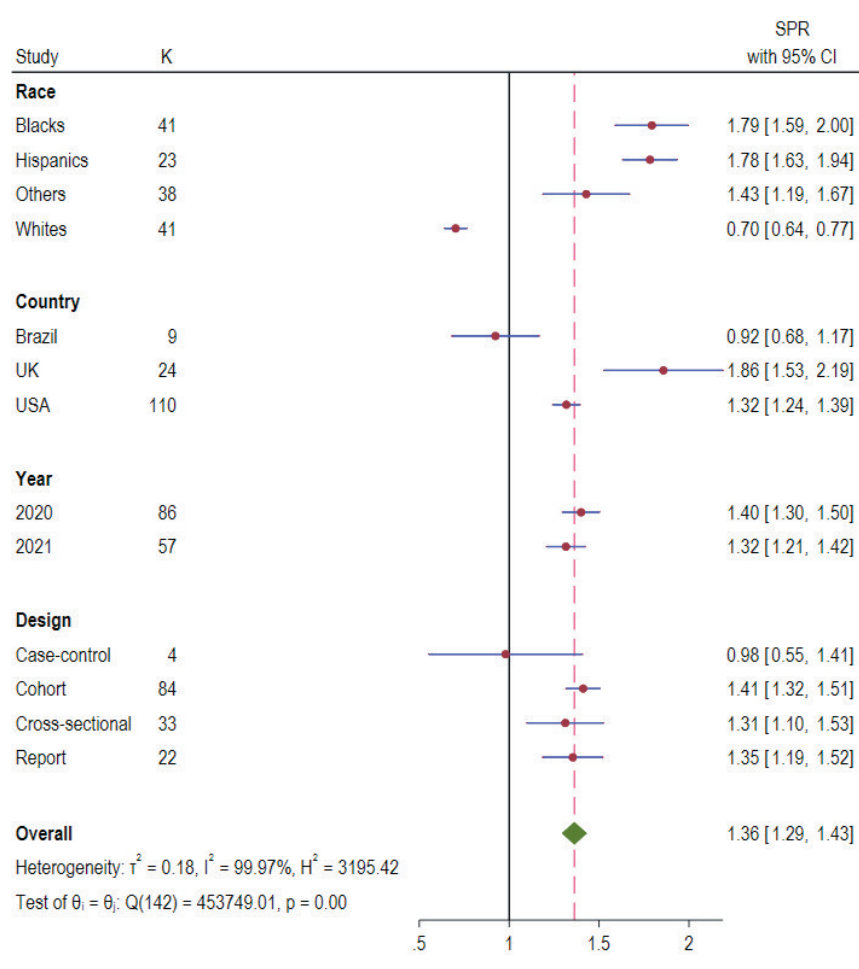

Figure 3. Standardised prevalence ratio (SPR) Forest plots of COVID-19 by race, country, year, and study design.
As shown in Figure 3, the overall pooled COVID-19 prevalence ratio for all population was 1.36 (95\% CI $=1.29-1.43$; $\left.I^{2}=99.97 \%, P<0.001\right)$. Subgroup analysis showed that UK had the highest of COVID-19 prevalence ratio, 1.86 (95\% $\mathrm{CI}=1.53,2.19)$, followed by USA, 1.32 (95\% CI $=1.53$, 2.19) and Brazil, 0.92 (95\% CI=0.68, 1.17). The COVID-19 prevalence ratio reported in studies published between the year 2020 and 2021 were $1.40(95 \% \mathrm{CI}=1.30,1.50)$ and 1.32 (95\% CI $=1.21,1.42)$, respectively. Cohort studies reported the highest COVID-19 prevalence ratio of 1.41 (95\% $\mathrm{CI}=1.32,1.51)$ followed by reports $1.35(95 \% \mathrm{CI}=1.19$, $1.52)$ and cross-sectional studies $1.31(95 \% \mathrm{CI}=1.10,1.53)$.

\section{COVID-19 hospitalisation ratio}

Thirty-six studies (48.6\%) (six reports [7,33,38,39,88], twenty-six cohorts $[16,28-32,36,40,41,43-50,59,69,78-$ $81,84,87,88]$, three cross-sectional $[35,42,86]$, and one case-control [60]) reported data with information on hospitalisation by race. The pooled estimate of hospitalisation ratio among Blacks was 1.87 (95\% CI $=1.69,2.04$; $\left.I^{2}=99.5 \%, P<0.001\right)($ Figure 4, Panel A), Hispanics 1.32 (95\% CI $=1.08,1.55 ; I^{2}=99.1 \%, P<0.001$ ) (Figure 4, Panel B), Other race groups 1.12 (95\% $\mathrm{CI}=0.89,1.35 ; I^{2}=99.7 \%$, $P<0.00$ ) (Figure 4, Panel C), and Whites 0.74 (95\% $\mathrm{CI}=0.65,0.82 ; I^{2}=99.7 \%, P<0.001$ ) (Figure 4, Panel D).

The pooled overall hospitalisation ratio was 1.23 (95\% CI=1.16, 1.29; $I^{2}=99.67 \%, P<0.001$ ) (Figure 5). Country level analysis showed that UK experienced the highest hospitalisation ratio 1.64 ( $95 \% \mathrm{CI}=1.38$, 1.90) followed by USA 1.22 ( $95 \% \mathrm{CI}=1.13,1.31)$ and Brazil 1.01 ( $95 \% \mathrm{CI}=0.96,1.06)$. Analysis by study designs found that cohort studies reported the highest hospitalisation ratio, 1.26 ( $95 \% \mathrm{CI}=1.18,1.33)$, followed by cross-sectional $1.03(95 \% \mathrm{CI}=0.87,1.18)$, reports $1.23(95 \% \mathrm{CI}=0.99-1.46)$ and case-control 0.95 $(95 \% \mathrm{CI}=0.60,1.31)$.

\section{COVID-19 mortality ratio}

Forty-two studies (56.8\%) (twenty-nine cohorts [12,28-32,34,36,40,41,43-50,52-57,89,90,93,96], four reports $[38,39,41,90]$ and nine cross-sectional studies $[35,42,51,58,91,94,95,97,98])$ reported data with information to determine mortality rates by race groups. Figure 6 presents the forest plots for mortality ratio by race. The plots showed that the pooled estimate for the mortality ratio in Blacks was 1.68 (95\% CI = 1.52, 1.83; $\left.I^{2}=99.5 \%, P<0.00\right)$ (Figure 6, Panel A), Hispanics 0.94 (95\% CI =0.84, 1.05; $\left.I^{2}=98.2 \%, P<0.00\right)$ (Figure 6, Panel B), Other race groups 1.06 (95\% CI=0.89, 1.23; $\left.I^{2}=99.8 \%, P<0.00\right)$ (Figure 6, Panel C), and Whites $0.82\left(95 \% \mathrm{CI}=0.78,0.87 ; I^{2}=99.1 \%, P<0.00\right.$ ) (Figure 6, Panel D).

The overall pooled mortality ratio for all population shown in Figure 7 was 1.13 (95\% CI=1.07, 1.1.20; $\left.I^{2}=99.75 \%, P<0.00\right)$. Mortality ratio by country was highest for UK 1.33 ( $95 \% \mathrm{CI}=1.10,1.57$ ), followed by USA $1.12(95 \% \mathrm{CI}=1.05,1.19)$, and Brazil 0.98 (95\% CI=0.98, 1.05). Report studies had the highest mortality ratio $1.42(95 \% \mathrm{CI}=1.03,1.82)$, followed by cohort $1.10(95 \% \mathrm{CI}=1.05,1.15)$, and cross-sectional 1.06 (95\% CI $=0.90,1.22)$.

\section{Meta-analysis and regression}

Table 1 shows the mean difference in COVID-19 outcomes for prevalence, hospitalisation, and mortality ratio. It was found that the prevalence ratio between Blacks and Whites was significant, -1.09 (95\% CI=-1.28, -0.90; $P<0.000$ ). A significant finding was also observed between Blacks and Other race groups, -0.35 (95\% $\mathrm{CI}=-0.55,-0.16 ; \mathrm{P}<0.000)$. However, the difference in COVID-19 prevalence ratio between Blacks and Hispanics was not significant, $0.11(95 \% \mathrm{CI}=-0.12,0.34 ; \mathrm{P}=0.34)$. For the mean difference in prevalence ratio by study designs, a significant difference was observed only between case-control and cohort study design, $0.48(95 \% \mathrm{CI}=0.04,0.93 ; P=0.03)$. No significant mean difference is prevalence ratio was found between the studies published in 2020 and 2021, -0.07 (95\% CI =-0.22, 0.09; $P=0.39$ ). 

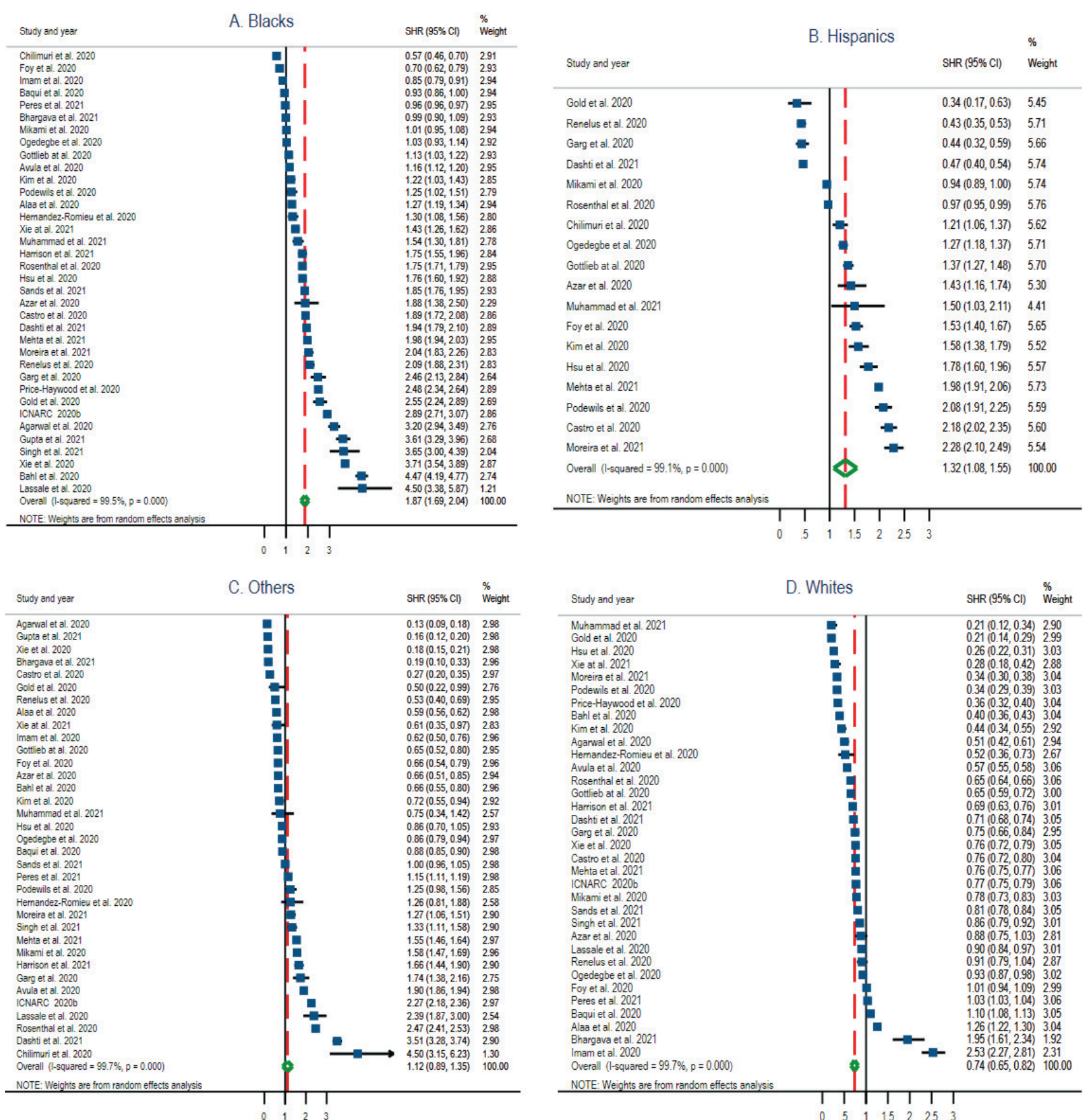

Figure 4. Standardised hospitalisation ratio (SHR) Forest plots of COVID-19 by selected race groups. Panel A: Blacks. Panel B: Hispanics. Panel C: Other race groups. Panel D: Whites.

For hospitalisation ratio, it was found that the mean difference in hospitalisation ratio in Blacks was significantly different from Whites $-1.11(95 \% \mathrm{CI}=-1.31,-0.91 ; P<0.001)$, Hispanics -0.49 (95\% CI =-0.73, -0.24 ; $P<0.001)$, and Other race groups $-0.77(95 \% \mathrm{CI}=-0.97,-0.56 ; P<0.001)$. Intercountry analysis showed COVID-19 mean difference in hospitalisation ratio was significant between Brazil and UK 0.67 (0.24, 1.09; $P<0.001$ ) but not between Brazil and USA 0.11 (95\% CI =-0.26, 0.49; $P=0.560)$. The mean difference in hospitalisation ratios between study designs were not significant.

The mean difference in mortality ratio between Blacks and Hispanics $-0.65(95 \% \mathrm{CI}=-0.83,-0.47 ; \mathrm{P}<0.00)$, Blacks and Whites $-0.82(95 \% \mathrm{CI}=-0.97,-0.68 ; \mathrm{P}<0.001)$, Blacks and Other race groups $-0.60(95 \% \mathrm{CI}=-0.75$, $-0.44 ; P<0.00)$ were all significant. Country level analysis showed that the mean difference between Brazil and UK was significant $0.27(95 \% \mathrm{CI}=0.01,0.53 ; P=0.04)$, but no difference existed between Brazil and USA $0.13(95 \% \mathrm{CI}=-0.10,0.35 ; P=0.28)$. Analysis for study design found that the mean difference 


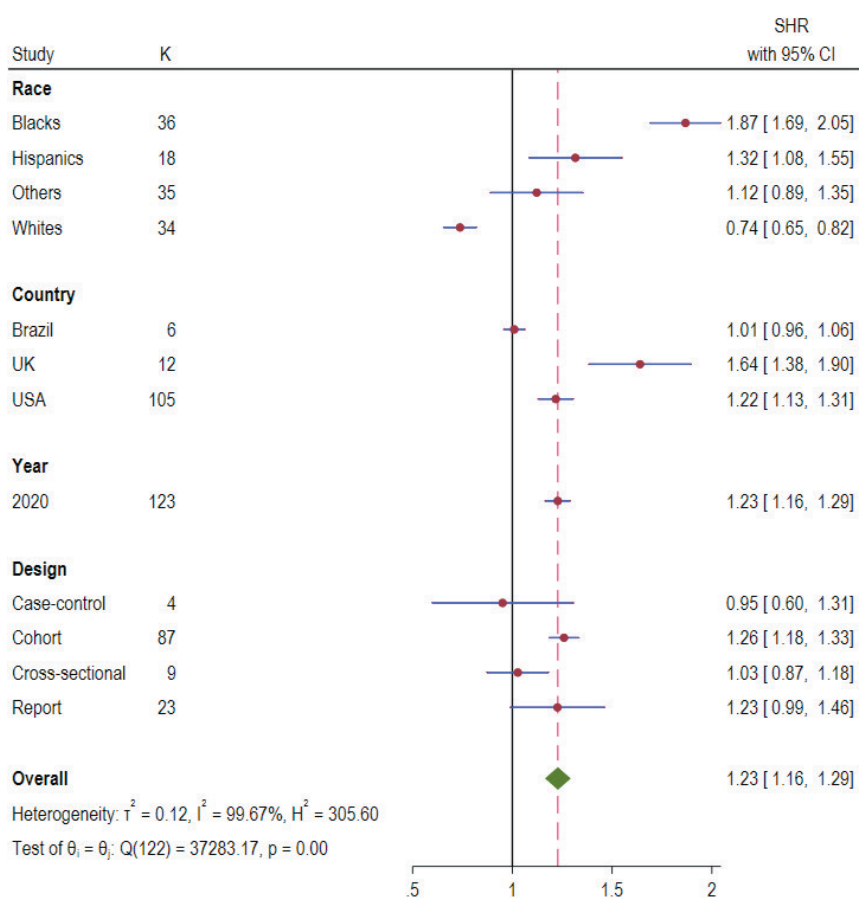

Figure 5. Standardised hospitalisation ratio (SHR) Forest plots of COVID-19 by race, country, year, and study design. in mortality ratio between cohorts and reports was significant, 0.26 (95\% CI=0.05, 0.46; P=0.01) but not between cohorts and cross-sectional studies, $-0.07(95 \% \mathrm{CI}=-0.21$, $0.07 ; P=0.32$ ).

\section{Publication bias}

Following correction for publication bias (Appendix S1-S3 and Figures S1-S3 in the Online Supplementary Document), the prevalence ratio among Blacks and Hispanics remained high; 1.38 (95\% CI $=1.19,1.57)$ for Blacks and $1.59(95 \% \mathrm{CI}=1.43,1.75)$ for Hispanics compared to 0.69 $(0.62,0.75)$ for Whites and $1.01(95 \% \mathrm{CI}=0.83,1.37)$ for Other race groups. For hospitalisation ratio, Blacks and Hispanics continued to have a high hospitalisation ratio even when corrected for publication bias compared to Whites and Other race groups. For example, the hospitalisation ratio for Black was 1.42 (95\% CI = 1.25, 1.59), Hispanics 1.32 (1.081.55) compared to 0.67 ( $95 \% \mathrm{CI}=0.59,0.75)$ for Whites and $0.74(0.49,0.98)$ for Other race groups. The mortality ratio for Blacks remained high, $1.32(1.17,1.45)$, compared to Hispanics 0.82 ( $95 \% \mathrm{CI}=0.70,0.93)$, Whites 0.82 (95\% $\mathrm{CI}=0.78,0.87)$ and Other race groups $0.83(95 \% \mathrm{CI}=0.67$, 0.99) following correction for publication bias.

\section{DISCUSSION}

The reviewed studies showed that COVID-19 significantly impacted Blacks across all the outcomes measured compared to Whites. The study found that the prevalence ratios in Blacks were 156\% higher than in Whites, for Hispanics were 154\% higher, and for Other race groups were 104\% higher. There was a significant difference between prevalence ratios in Blacks and Whites and Other race groups but not Hispanics. Hospitalisation ratios in Blacks were 153\% higher than in Whites, for Hispanics were 78\% higher, and for Other race groups were $51 \%$ higher. A significant difference was found between hospitalisation in Blacks and Hispanics, Whites and Other race groups. Deaths in Blacks were 105\% higher than in Whites, Hispanics were 15\% higher, and Other race groups were 29\% higher. Mortality in Blacks was significantly different from Whites, Hispanics, and Other race groups. Intercountry differences were also observed regarding prevalence ratios of COVID-19. The prevalence ratio in the USA was 102\% higher than Brazil's, and UK's was 43\% higher than Brazil's. Although Blacks and Hispanics experienced a similar burden of COVID-19, Blacks had higher hospitalisation and mortality ratios than Hispanics, Whites and Other race groups.

The identified racial disparities in prevalence, hospitalisations and mortality ratio from COVID-19 could be attributed to several reasons. It could be that Blacks, Hispanics, and Other racial groups experience higher socioeconomic disadvantages that increase their risk of contracting COVID-19. People in higher socioeconomic status and affluent neighbourhoods have been reported to be less likely to acquire COVID-19 infection, whereas social and economic disadvantages have been associated with higher COVID-19 infections [99,100].

Evidence suggests that racial minorities in urban settings tend to live in more crowded conditions and are more likely to be employed in public-facing occupations (for example, services and transportation), making practising social distancing practically impossible $[13,15,101]$. For example, one study found that Blacks and Latinos working in essential services experienced higher COVID-19 mortality rates than Whites [102]. The authors observed that many Blacks held the top nine essential jobs that exposed them to the risk of catching COVID-19, increasing the potentials of infecting their families. Another study found that frontline jobs mainly occupied by Blacks and Hispanics were risk factors to COVID-19 [103]. Despite racial minorities being at increased risk of exposure to the virus, they experience increased barriers to testing, such as health care access, which contributes to delays in obtaining testing until they are in a more serious condition resulting in poor health outcomes [101].

Structural racism as a key determinant of population health can also explain the disproportionate burdens of COVID-19 found among racial minorities across the outcomes measured in the current study [104]. While 

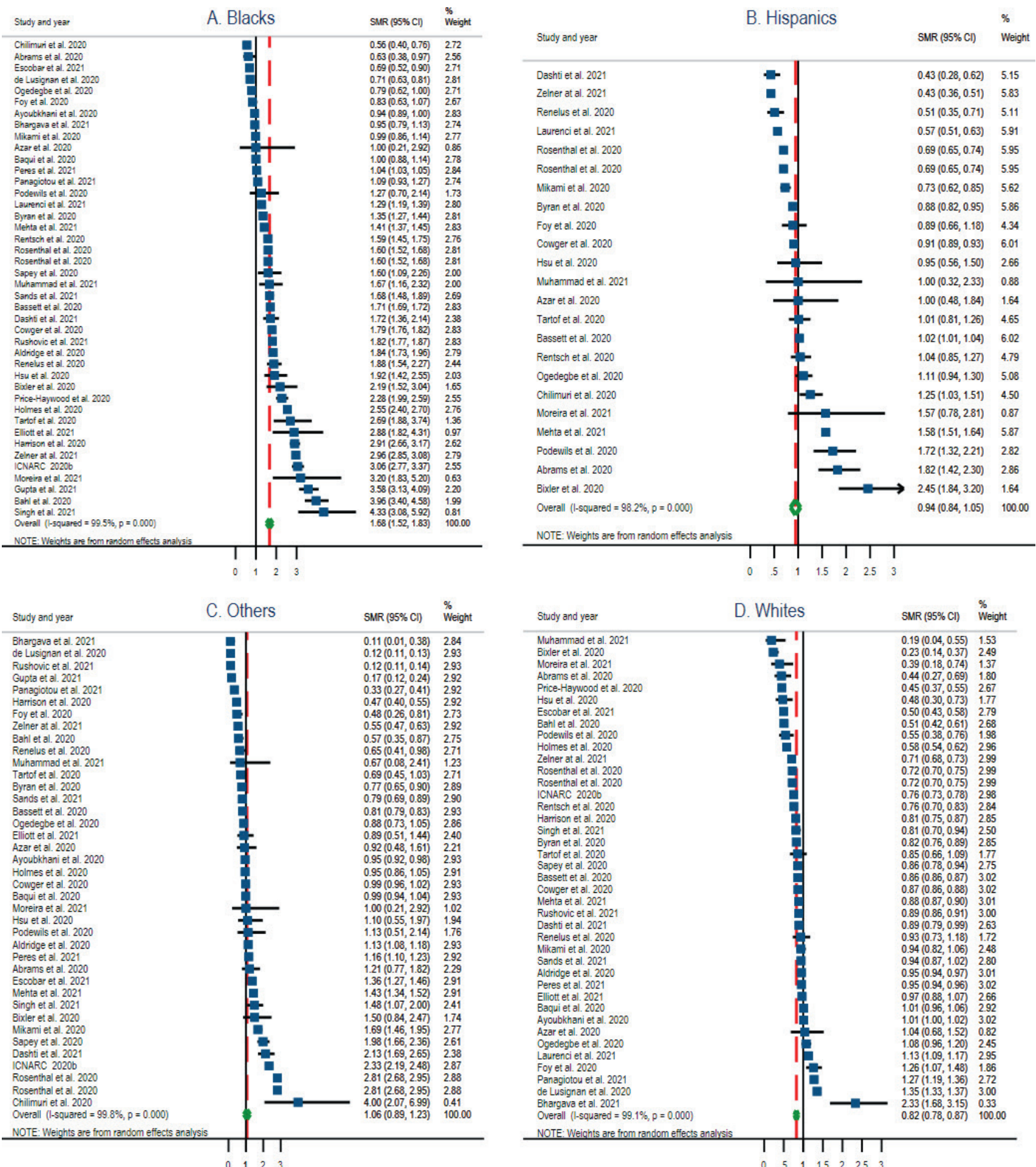

Figure 6. Standardised mortality ratio (SMR) Forest plots of COVID-19 by selected race groups. Panel A: Blacks. Panel B: Hispanics. Panel C: Other race groups. Panel D: Whites.

there are differences between and within countries relating to the experience of structural racism and health inequities because of differences in policies and forces that facilitate these issues, these systems of oppression can lead to health inequities because of experienced disadvantages and lack of opportunities $[105,106]$.

Blacks, Hispanics, and Other minority racial populations experience disproportionately higher rates of other underlying health conditions, making them more vulnerable to COVID-19. For example, a report found that neighbourhoods with higher poverty rates occupied by Blacks and Hispanics experienced disproportionate diabetes and hypertension comorbidities and higher rates of COVID-19 infections [103]. Other studies have 


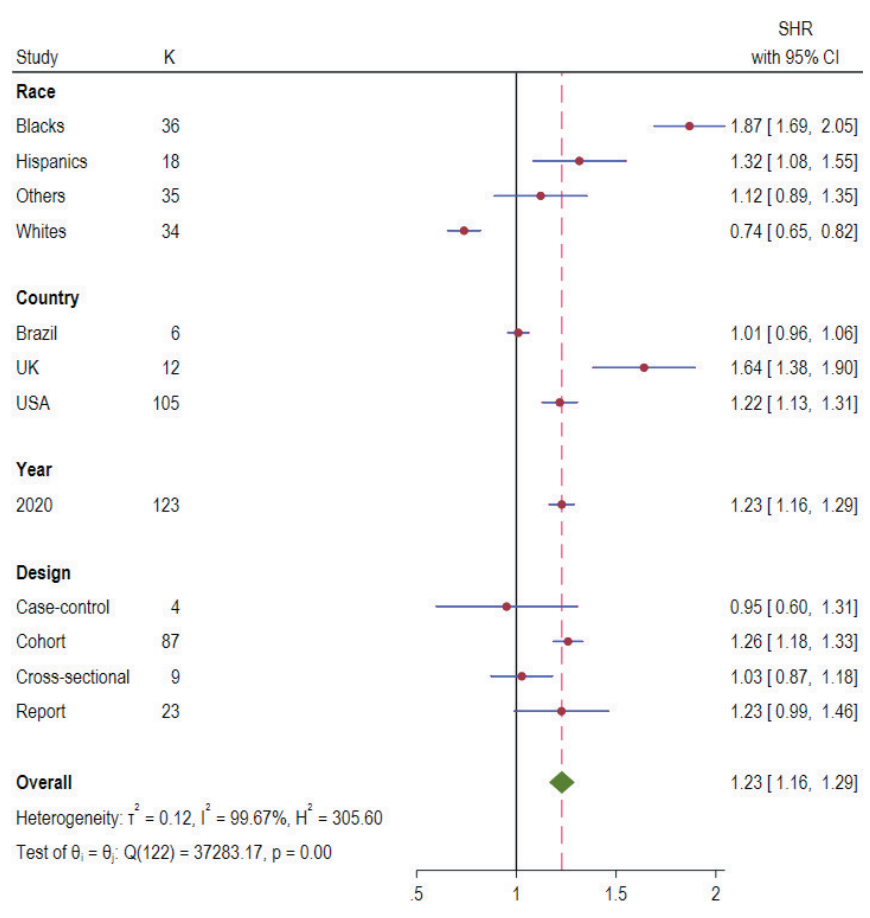

Figure 7. Standardised mortality ratio (SMR) Forest plots of COVID-19 by race, country, year, and study design. shown that comorbidities such as obesity and cardiovascular diseases, where Blacks and Others are disproportionately overrepresented, were a risk factor for COVID-19 related mortality [6,107-109]. It may also be that older Blacks, Hispanics and Other racial minority groups have higher comorbidities than Whites, increasing their risks to COVID-19. Older age, regardless of race, has, however, been identified as a risk factor to COVID-19 [107,110,111].

Other factors, such as underlying health conditions and old age, could have contributed to the increased risk of COVID-19 in minority populations $[42,60,112,113]$. However, many underlying health conditions result from years of systemic inequities in social determinants of health, including poor housing, lack of employment, low income, racism, poor neighbourhood, and poor working and living conditions experienced by minority populations in western countries [112,114-117]. For example, residents in poor neighbourhoods with a poorly built environment to facilitate physical activities are less likely to participate in physical activities and are more likely to live sedentary lifestyles [118]. Sedentary lifestyles and lack of physical activities are risk factors for cardiovascular-related health conditions, including but not limited to hypertension, diabetes, and obesity [112]. In countries such as the United States, issues related to structural determinants of health are prevalent and
ulations, which leads to generational inequities $[99,119]$.

disproportionately experienced by minority populations, which leads to generational inequities [99,119].
Given these findings, there is a need for a shift of focus from treating comorbidities from clinical perspectives only to addressing broader socioeconomic and structural determinants of health disadvantages experienced by most Blacks, Hispanics and Other minority groups in western countries [120]. Unprecedentedly, COVID-19 has exposed the social disadvantages that Blacks, Hispanics and Other minority populations continue to experience because of racism, discrimination, and systemic institutional policy of racial suppression in western countries [104]. Governments and policymakers have an opportunity to turn the course of health inequities in minority populations by investing in programs that facilitate equity in disadvantaged communities for improved health outcomes.

Table 1. Meta-regression of Mean difference for prevalence, hospitalisation, and mortality ratios by subgroups

\begin{tabular}{|c|c|c|c|}
\hline OUTCOMES & PARAMETERS & MEAN DIFFERENCE $(95 \% \mathrm{Cl})$ & P VALUE \\
\hline \multicolumn{4}{|c|}{ Prevalence ratio } \\
\hline \multirow[t]{4}{*}{ Race } & Black & Ref & \\
\hline & Hispanics & $0.11(-0.12,0.34)$ & 0.343 \\
\hline & Other & $-0.35(-0.55,-0.16)$ & $<0.001$ \\
\hline & White & $-1.09(-1.28,-0.90)$ & $<0.001$ \\
\hline \multirow[t]{3}{*}{ Country } & Brazil & Ref & . \\
\hline & UK & $0.91(0.56,1.26)$ & $<0.001$ \\
\hline & USA & $0.19(-0.13,0.51)$ & 0.248 \\
\hline \multirow[t]{2}{*}{ Year } & 2020 & Ref & . \\
\hline & 2021 & $-0.07(-0.22,0.09)$ & 0.387 \\
\hline \multirow[t]{4}{*}{ Design } & Case-control & Ref & . \\
\hline & Cohort & $0.48(0.04,0.93)$ & 0.033 \\
\hline & Cross-sectional & $0.25(-0.22,0.72)$ & 0.302 \\
\hline & Report & $0.24(-0.23,0.71)$ & 0.312 \\
\hline \multicolumn{4}{|c|}{ Hospitalisation ratio } \\
\hline \multirow[t]{4}{*}{ Race } & Black & Ref & \\
\hline & Hispanics & $-0.49(-0.73,-0.24)$ & $<0.001$ \\
\hline & Other & $-0.77(-0.97,-0.56)$ & $<0.001$ \\
\hline & White & $-1.11(-1.31,-0.91)$ & $<0.001$ \\
\hline
\end{tabular}

\begin{tabular}{|c|c|c|c|}
\hline OUTCOMES & PARAMETERS & MEAN DIFFERENCE $(95 \% \mathrm{Cl})$ & P VALUE \\
\hline \multirow[t]{3}{*}{ Country } & Brazil & Ref & . \\
\hline & UK & $0.67(0.24,1.09)$ & $<0.001$ \\
\hline & USA & $0.11(-0.26,0.49)$ & 0.558 \\
\hline \multirow[t]{4}{*}{ Design } & Case-control & $0.00(0.00,0.00)$ &. \\
\hline & Cohort & $0.30(-0.12,0.72)$ & 0.158 \\
\hline & Cross-sectional & $0.11(-0.42,0.63)$ & 0.691 \\
\hline & Report & $0.21(-0.24,0.65)$ & 0.366 \\
\hline \multicolumn{4}{|c|}{ Mortality ratio } \\
\hline \multirow[t]{4}{*}{ Race } & Black & Ref & \\
\hline & Hispanics & $-0.65(-0.83,-0.47)$ & $<0.001$ \\
\hline & Other & $-0.60(-0.75,-0.44)$ & $<0.001$ \\
\hline & White & $-0.82(-0.97,-0.68)$ & 0.00 \\
\hline \multirow[t]{3}{*}{ Country } & Brazil & Ref & . \\
\hline & UK & $0.27(0.01,0.53)$ & 0.039 \\
\hline & USA & $0.13(-0.10,0.35)$ & 0.276 \\
\hline \multirow[t]{3}{*}{ Design } & Cohort & Ref & . \\
\hline & Cross-sectional & $-0.07(-0.21,0.07)$ & 0.318 \\
\hline & Report & $0.26(0.05,0.46)$ & 0.014 \\
\hline
\end{tabular}

CI - confidence interval 


\section{Limitations and strengths}

There are a few limitations to consider when interpreting the finding from this article. The included studies used different study designs and populations that could have influenced the selection of study participants and protocols, and thus, the findings. Some studies did not clearly describe whether race was self-reported and could have misclassified the race of some patients, which could have led to under-or over-reporting of COVID-19 outcomes. The included studies did not have data on many moderators, and we could not conduct a meta-analysis controlling for them. The different sources of data used by the different studies (for example, hospital data and sentinel data), differences in specificity and sensitivity of tests used could have contributed to the high heterogeneity observed among the studies, and the differences in the ascertainment of death outcomes are important limitations to note. Lastly, we did not search for all the grey literature, which could have inadvertently led to the omission of additional potential studies. It is, therefore, important to interpret our findings with these limitations in mind.

An important strength of this paper is its methodologically rigorous analysis that involved correcting for publication bias and synthesising the findings to highlight the extent of the disproportionate burden of COVID-19 in racial minority groups. This means that the findings cannot be attributed to publication bias which ensures confidence in the finding. Another strength of this review is its use of meta-regression analysis controlling for the different parameters, and this was vital to compare the results by sub-groups. Our findings highlight the disproportionate burdens of COVID-19 outcomes among the selected race groups.

\section{CONCLUSIONS}

The burden of COVID-19 in terms of prevalence, hospitalisation, and mortality rate was disproportionately higher among Blacks and Hispanics compared with Whites. These findings point to the systemic disadvantages experienced by racial minority populations and highlight the need to address inequities in these communities by developing programs that improve overall health outcomes. Further work and more well-designed longitudinal studies are needed to expand the knowledge on racial differences in COVID-19 outcomes and to identify the social determinants of health shaping the disparities in the outcome of COVID-19 among racial minority populations.

\footnotetext{
Ethics: No ethical approval was required as the study used secondary data from published articles.
Funding: None.
Authorship contribution: Conceptualisation: WM; Methodology: WM, VO, CN; Formal analysis and investigation: WM
VO, TN; Writing - original draft preparation: WM, TN, CN, LM, VO; Writing - review and editing: WM, VO, LM, TN
CN. All authors have approved this manuscript for publication.
Competing interest: The authors completed the ICMJE Unified Competing Interest form (available upon request from
the corresponding author), and declare no conflicts of interest.
Additional material
Online Supplementary Document
}

$1 \mathrm{Wu}$ Z, McGoogan JM. Characteristics of and Important Lessons From the Coronavirus Disease 2019 (COVID-19) Outbreak in China: Summary of a Report of 72314 Cases From the Chinese Center for Disease Control and Prevention. JAMA. 2020;323:1239-42. Medline:32091533 doi:10.1001/jama.2020.2648

2 Boldog P, Tekeli T, Vizi Z, Dénes A, Bartha FA, Röst G. Risk Assessment of Novel Coronavirus COVID-19 Outbreaks Outside China. J Clin Med. 2020;9:571. Medline:32093043 doi:10.3390/jcm9020571

$3 \mathrm{WHO}$. Statement on the second meeting of the International Health Regulations (2005) Emergency Committee regarding the outbreak of novel coronavirus (2019-nCoV). 2020. Available: https:/www.who.int/news-room/detail/30-01-2020-statementon-the-second-meeting-of-the-international-health-regulations-(2005)-emergency-committee-regarding-the-outbreak-of-novel-coronavirus-(2019-ncov). Accessed: 10 September 2020.

4 WHO. WHO Director-General's opening remarks at the media briefing on COVID-19 - 11 March 2020. 2020. Available: https://www.who.int/dg/speeches/detail/who-director-general-s-opening-remarks-at-the-media-briefing-on-covid-19---11march-2020. Accessed: 18 September 2020.

5 World Health Organization. WHO Coronavirus Disease (COVID-19) Dashboard. 2021. Available: https://covid19.who.int/. Accessed: 24 May 2021. 
6 Franki R. Comorbidities increase COVID-19 deaths by a factor of 12: Hispanic, Black, and Native persons account for a disproportionate share of those infected by the coronavirus. Neurology Reviews. 2020;28:45.

7 Garg S, Kim L, Whitaker M, O'Halloran A, Cummings C, Holstein R, et al. Hospitalization Rates and Characteristics of Patients Hospitalized with Laboratory-Confirmed Coronavirus Disease 2019 - COVID-NET, 14 States, March 1-30, 2020. MMWR Morb Mortal Wkly Rep. 2020;69:458-64. Medline:32298251 doi:10.15585/mmwr.mm6915e3

8 Holtgrave DR, Barranco MA, Tesoriero JM, Blog DS, Rosenberg ES. Assessing racial and ethnic disparities using a COVID-19 outcomes continuum for New York State. Ann Epidemiol. 2020;48:9-14. Medline:32723697 doi:10.1016/j.annepidem.2020.06.010

9 Khunti K, Singh AK, Pareek M, Hanif W. Is ethnicity linked to incidence or outcomes of covid-19? BMJ. 2020;369:m1548. Medline:32312785 doi:10.1136/bmj.m1548

10 Pareek M, Bangash MN, Pareek N, Pan D, Sze S, Minhas JS, et al. Ethnicity and COVID-19: an urgent public health research priority. Lancet. 2020;395:1421-2. Medline:32330427 doi:10.1016/S0140-6736(20)30922-3

11 Okoh AK, Sossou C, Dangayach NS, Meledathu S, Phillips O, Raczek C, et al. Coronavirus disease 19 in minority populations of Newark, New Jersey. Int J Equity Health. 2020;19:93. Medline:32522191 doi:10.1186/s12939-020-01208-1

12 Aldridge RW, Lewer D, Katikireddi S, Mathur R, Pathak N, Burns R, et al. Black, Asian and Minority Ethnic groups in England are at increased risk of death from COVID-19: indirect standardisation of NHS mortality data. Wellcome Open Res. 2020;5:88. Medline:32613083 doi:10.12688/wellcomeopenres.15922.2

13 Webb Hooper M, Nápoles AM, Pérez-Stable EJ. COVID-19 and Racial/Ethnic Disparities. JAMA. 2020;323:2466-7. Medline:32391864 doi:10.1001/jama.2020.8598

14 Ravi K. Ethnic disparities in COVID-19 mortality: are comorbidities to blame? In: Cockerham WC, Cockerham GB, editors. The COVID-19 Reader: The Science and What it Says About The Social. 1 st Edition. ed. Philadelphia, Pennsylvania: Routledge; 2020.

15 Public Health England. Disparities in the risk and outcomes of COVID-19. 2020. Available: https://assets.publishing.service gov.uk/government/uploads/system/uploads/attachment_data/file/892085/disparities_review.pdf. Accessed: 10 December 2020.

16 Harrison E, Docherty A, Semple C. CO-CIN. Investigating associations between ethnicity and outcome from COVID-19. 2020. 2020. Available: https://assets.publishing.service.gov.uk/government/uploads/system/uploads/attachment_data/file/886433/ s0238-co-cin-report-ethnicity-outcomes-250420-sage29.pdf. Accessed: 10 December 2020.

17 Pan D, Sze S, Minhas JS, Bangash MN, Pareek N, Divall P, et al. The impact of ethnicity on clinical outcomes in COVID-19: A systematic review. EClinicalMedicine. 2020;23:100404. Medline:32632416 doi:10.1016/j.eclinm.2020.100404

18 Moher D, Liberati A, Tetzlaff J, Altman DG. The PG. Preferred Reporting Items for Systematic Reviews and Meta-Analyses: The PRISMA Statement. PLoS Med. 2009;6:e1000097. Medline:19621072 doi:10.1371/journal.pmed.1000097

19 Agyemang C, Bhopal R, Bruijnzeels M. Negro, Black, Black African, African Caribbean, African American or what? Labelling African origin populations in the health arena in the 21st century. J Epidemiol Community Health. 2005;59:1014. Medline:16286485 doi:10.1136/jech.2005.035964

20 Bhopal R. Glossary of terms relating to ethnicity and race: for reflection and debate. J Epidemiol Community Health. 2004;58:441. Medline:15143107 doi:10.1136/jech.2003.013466

21 JBI. Critical appraisal tools. 2020. Available: https://joannabriggs.org/critical-appraisal-tools. Accessed: 15 October 2020.

22 United States Census Bureau. QuickFacts. 2020. Available: https://www.census.gov/quickfacts/fact/table/US/PST045219. Accessed: 15 May 2021.

23 UK Government. Ethnicity facts and figures. 2020. Available: https://www.ethnicity-facts-figures.service.gov.uk/uk-population-by-ethnicity/national-and-regional-populations/population-of-england-and-wales/latest. Accessed: 15 May 2021.

24 Breslow N, Day N. Statistical Methods in Cancer Research: Volume II - The Design and Analysis of Cohort Studies. Lyon: International Agency for Research on Cancer; 1987.

25 Duval S, Tweedie R. Trim and Fill: A Simple Funnel-Plot-Based Method of Testing and Adjusting for Publication Bias in Meta-Analysis. Biometrics. 2000;56:455-63. Medline:10877304 doi:10.1111/j.0006-341X.2000.00455.x

26 Duval S, Tweedie RA. Nonparametric "Trim and Fill" Method of Accounting for Publication Bias in Meta-Analysis. J Am Stat Assoc. 2000;95:89-98.

27 Harris R, Bradburn M, Deeks J, Harbord R, Altman DG, Steichen T, et al. METAN: Stata module for fixed and random effects meta-analysis, Statistical Software Components S456798. 2006. Available: https://ideas.repec.org/s/boc/bocode.html. Accessed: 15 August 2020.

28 Dashti H, Roche EC, Bates DW, Mora S, Demler O. SARS2 simplified scores to estimate risk of hospitalization and death among patients with COVID-19. Sci Rep. 2021;11:4945. Medline:33654180 doi:10.1038/s41598-021-84603-0

29 Mehta HB, Li S, Goodwin JS. Risk Factors Associated With SARS-CoV-2 Infections, Hospitalization, and Mortality Among US Nursing Home Residents. JAMA Netw Open. 2021;4:e216315. Medline:33787905 doi:10.1001/jamanetworkopen.2021.6315

30 Mikami T, Miyashita H, Yamada T, Harrington M, Steinberg D, Dunn A, et al. Risk Factors for Mortality in Patients with COVID-19 in New York City. J Gen Intern Med. 2021;36:17-26. Medline:32607928 doi:10.1007/s11606-020-05983-z

31 Moreira A, Chorath K, Rajasekaran K, Burmeister F, Ahmed M, Moreira A. Demographic predictors of hospitalization and mortality in US children with COVID-19. Eur J Pediatr. 2021;180:1659-63. Medline:33474580 doi:10.1007/s00431-021-03955-x

32 Ogedegbe G, Ravenell J, Adhikari S, Butler M, Cook T, Francois F, et al. Assessment of Racial/Ethnic Disparities in Hospitalization and Mortality in Patients With COVID-19 in New York City. JAMA Netw Open. 2020;3:e2026881. Medline:33275153 doi:10.1001/jamanetworkopen.2020.26881

33 Podewils LJ, Burket TL, Mettenbrink C, Steiner A, Seidel A, Scott K, et al. Disproportionate Incidence of COVID-19 Infection, Hospitalizations, and Deaths Among Persons Identifying as Hispanic or Latino - Denver, Colorado March-October 2020. MMWR Morb Mortal Wkly Rep. 2020;69:1812-6. Medline:33270613 doi:10.15585/mmwr.mm6948a3 
34 Rosenthal N, Cao Z, Gundrum J, Sianis J, Safo S. Risk Factors Associated With In-Hospital Mortality in a US National Sample of Patients With COVID-19. JAMA Netw Open. 2020;3:e2029058. Medline:33301018 doi:10.1001/jamanetworkopen.2020.29058

35 Singh BM, Bateman J, Viswanath A, Klaire V, Mahmud S, Nevill A, et al. Risk of COVID-19 hospital admission and COVID-19 mortality during the first COVID-19 wave with a special emphasis on ethnic minorities: an observational study of a single, deprived, multiethnic UK health economy. BMJ Open. 2021;11:e046556. Medline:33597146 doi:10.1136/bmjopen-2020-046556

36 Azar KM, Shen Z, Romanelli RJ, Lockhart SH, Smits K, Robinson S, et al. Disparities In Outcomes Among COVID-19 Patients In A Large Health Care System In California. Health Aff (Millwood). 2020;39:1253-62. Medline:32437224 doi:10.1377/ hlthaff.2020.00598

37 Hsu P, Hayes-Bautista DE. The Epidemiology of Diversity: COVID-19 Case Rate Patterns in California. J Immigr Minor Health. 2021;23:1-6. Medline:33620661

38 ICNARC. ICNARC report on COVID-19 in critical care - 07 September 2020. London: Intensive care national audit and research centre (ICNARC); 2020.

39 Hsu HE, Ashe EM, Silverstein M, Hofman M, Lange SJ, Razzaghi H, et al. Race/Ethnicity, Underlying Medical Conditions, Homelessness, and Hospitalization Status of Adult Patients with COVID-19 at an Urban Safety-Net Medical Center-Boston, Massachusetts, 2020. MMWR Morb Mortal Wkly Rep. 2020;69:864-9. Medline:32644981 doi:10.15585/mmwr.mm6927a3

40 Price-Haywood EG, Burton J, Fort D, Seoane L. Hospitalization and Mortality among Black Patients and White Patients with Covid-19. N Engl J Med. 2020;382:2534-43. Medline:32459916 doi:10.1056/NEJMsa2011686

41 Bahl A, Van Baalen MN, Ortiz L, Chen NW, Todd C, Milad M, et al. Early predictors of in-hospital mortality in patients with COVID-19 in a large American cohort. Intern Emerg Med. 2020;15:1485-99. Medline:32970246 doi:10.1007/s11739-02002509-7

42 Baqui P, Bica I, Marra V, Ercole A. Schaar Mvd. Ethnic and regional variations in hospital mortality from COVID-19 in Brazil: a cross-sectional observational study. Lancet Glob Health. 2020;8:e1018-26. Medline:32622400 doi:10.1016/S2214109X(20)30285-0

43 Bhargava A, Szpunar SM, Sharma M, Fukushima EA, Hoshi S, Levine M, et al. Clinical Features and Risk Factors for In-Hospital Mortality From COVID-19 Infection at a Tertiary Care Medical Center, at the Onset of the US COVID-19 Pandemic. J Intensive Care Med. 2021;36:711-8. Medline:33759606 doi:10.1177/08850666211001799

44 Chilimuri S, Haozhe S, Alemam A, Mantri N, Shehi E, Tejada J, et al. Predictors of Mortality in Adults Admitted with COVID-19: Retrospective Cohort Study from New York City. West J Emerg Med. 2020;21:779-84. Medline:32726241 doi:10.5811/westjem.2020.6.47919

45 Foy BH, Carlson JCT, Reinertsen E, Padros I, Valls R, Pallares Lopez R, Palanques-Tost E, et al. Association of Red Blood Cell Distribution Width With Mortality Risk in Hospitalized Adults With SARS-CoV-2 Infection. JAMA Netw Open. 2020;3:e2022058. Medline:32965501 doi:10.1001/jamanetworkopen.2020.22058

46 Gupta R, Agrawal R, Bukhari Z, Jabbar A, Wang D, Diks J, et al. Higher comorbidities and early death in hospitalized African-American patients with Covid-19. BMC Infect Dis. 2021;21:78. Medline:33461499 doi:10.1186/s12879-021-05782-9

47 Muhammad R, Ogunti R, Ahmed B, Munawar M, Donaldson S, Sumon M, et al. Clinical Characteristics and Predictors of Mortality in Minority Patients Hospitalized with COVID-19 Infection. J Racial Ethn Health Disparities. 2021. Online ahead of print. Medline:33538998 doi:10.1007/s40615-020-00961-x

48 Peres IT, Bastos LSL, Gelli JGM, Marchesi JF, Dantas LF, Antunes BBP, et al. Sociodemographic factors associated with COVID-19 in-hospital mortality in Brazil. Public Health. 2021;192:15-20. Medline:33607516 doi:10.1016/j.puhe.2021.01.005

49 Renelus BD, Khoury NC, Chandrasekaran K, Bekele E, Briggs WM, Ivanov A, et al. Racial Disparities in COVID-19 Hospitalization and In-hospital Mortality at the Height of the New York City Pandemic. J Racial Ethn Health Disparities. 2020. Online ahead of print. Medline:32946070 doi:10.1007/s40615-020-00872-x

50 Sands KE, Wenzel RP, McLean LE, Korwek KM, Roach JD, Miller KM, et al. Patient characteristics and admitting vital signs associated with coronavirus disease 2019 (COVID-19)-related mortality among patients admitted with noncritical illness. Infect Control Hosp Epidemiol. 2020;42:399-405. Medline:32928319 doi:10.1017/ice.2020.461

51 Escobar AL, Rodriguez TDM, Monteiro JC. Lethality and characteristics of deaths due to COVID-19 in Rondonia: an observational study. Epidemiol Serv Saude. 2021;30:e2020763. Medline:33331602 doi:10.1590/s1679-49742021000100019

52 Harrison SL, Fazio-Eynullayeva E, Lane DA, Underhill P, Lip GYH. Comorbidities associated with mortality in 31,461 adults with COVID-19 in the United States: A federated electronic medical record analysis. PLoS Med. 2020;17:e1003321. Medline:32911500 doi:10.1371/journal.pmed.1003321

53 Panagiotou OA, Kosar CM, White EM, Bantis LE, Yang X, Santostefano CM, et al. Risk Factors Associated With All-Cause 30-Day Mortality in Nursing Home Residents With COVID-19. JAMA Intern Med. 2021;181:439-48. Medline:33394006 doi:10.1001/jamainternmed.2020.7968

54 Sapey E, Gallier S, Mainey C, Nightingale P, McNulty D, Crothers H, et al. Ethnicity and risk of death in patients hospitalised for COVID-19 infection in the UK: an observational cohort study in an urban catchment area. BMJ Open Respir Res. 2020;7:e000644. Medline:32873607 doi:10.1136/bmjresp-2020-000644

55 Tartof SY, Lei Q, Hong V, Rong W, Nadjafi RF, Fischer H, et al. Obesity and Mortality Among Patients Diagnosed With COVID-19: Results From an Integrated Health Care Organization. Ann Intern Med. 2020;173:773-81. Medline:32783686 doi:10.7326/M20-3742

56 Zelner J, Trangucci R, Naraharisetti R, Cao A, Malosh R, Broen K, et al. Racial Disparities in Coronavirus Disease 2019 (COVID-19) Mortality Are Driven by Unequal Infection Risks. Clin Infect Dis. 2021;72:e88-95. Medline:33221832 doi:10.1093/ $\mathrm{cid} / \mathrm{ciaal} 723$ 
57 Rentsch CT, Kidwai-Khan F, Tate JP, Park LS, King JT, Skanderson M, et al. Patterns of COVID-19 testing and mortality by race and ethnicity among United States veterans: A nationwide cohort study. PLoS Med. 2020;17:e1003379. Medline:32960880 doi:10.1371/journal.pmed.1003379

58 Holmes L Jr, Enwere M, Williams J, Ogundele B, Chavan P, Piccoli T, et al. Black-white risk differentials in COVID-19 (SARSCoV2) transmission, mortality and case fatality in the United States: translational epidemiologic perspective and challenges. Int J Environ Res Public Health. 2020;17:4322. Medline:32560363 doi:10.3390/ijerph17124322

59 Lassale C, Gaye B, Hamer M, Gale CR, Batty GD. Ethnic disparities in hospitalisation for COVID-19 in England: The role of socioeconomic factors, mental health, and inflammatory and pro-inflammatory factors in a community-based cohort study. Brain Behav Immun. 2020;88:44-9. Medline:32497776 doi:10.1016/j.bbi.2020.05.074

60 Gottlieb M, Sansom S, Frankenberger C, Ward E, Hota B. Clinical Course and Factors Associated With Hospitalization and Critical Illness Among COVID-19 Patients in Chicago, Illinois. Acad Emerg Med. 2020;27:963-73. Medline:32762106 doi:10.1111/acem.14104

61 Anand S, Montez-Rath M, Han J, Bozeman J, Kerschmann R, Beyer P, et al. Prevalence of SARS-CoV-2 antibodies in a large nationwide sample of patients on dialysis in the USA: a cross-sectional study. Lancet. 2020;396:1335-44. Medline:32987007 doi:10.1016/S0140-6736(20)32009-2

62 Butt AA, Yan P. Rates and characteristics of SARS-CoV-2 infection in persons with hepatitis C virus infection. Liver Int. 2021;41:76-80. Medline:33006798 doi:10.1111/liv.14681

63 Egede LE, Walker RJ, Garacci E, Raymond JR Sr. Racial/Ethnic Differences In COVID-19 Screening, Hospitallization, And Mortality In Southeast Wisconsin. Health Aff (Millwood). 2020;39:1926-34. Medline:33136498 doi:10.1377/hlthaff.2020.01081

64 Horta BL, Silveira MF, Barros AJD, Barros FC, Hartwig FP, Dias MS, et al. Prevalence of antibodies against SARS-CoV-2 according to socioeconomic and ethnic status in a nationwide Brazilian survey. Rev Panam Salud Publica. 2020;44:e135. Medline:33165337 doi:10.26633/RPSP.2020.135

65 Joy M, Hobbs FDR, Bernal JL, Sherlock J, Amirthalingam G, McGagh D, et al. Excess mortality in the first COVID pandemic peak: cross-sectional analyses of the impact of age, sex, ethnicity, household size, and long-term conditions in people of known SARS-CoV-2 status in England. Br J Gen Pract. 2020;70:e890-8. Medline:33077508 doi:10.3399/bjgp20X713393

66 Inagaki K, Garg P, Hobbs CV. SARS-CoV-2 Positivity Rates Among Children of Racial and Ethnic Minority Groups in Mississippi. Pediatrics.2021;147:e2020024349. Medline:33115793 doi:10.1542/peds.2020-024349

67 Kosar CM, White EM, Feifer RA, Blackman C, Gravenstein S, Panagiotou OA, et al. COVID-19 Mortality Rates Among Nursing Home Residents Declined From March To November 2020. Health Aff (Millwood). 2021;40:655-63. Medline:33705204 doi:10.1377/hlthaff.2020.02191

68 Livingston G, Rostamipour H, Gallagher P, Kalafatis C, Shastri A, Huzzey L, et al. Prevalence, management, and outcomes of SARS-CoV-2 infections in older people and those with dementia in mental health wards in London, UK: a retrospective observational study. Lancet Psychiatry. 2020;7:1054-63. Medline:33031760 doi:10.1016/S2215-0366(20)30434-X

69 Rosenberg ES, Tesoriero JM, Rosenthal EM, Chung R, Barranco MA, Styer LM, et al. Cumulative incidence and diagnosis of SARSCoV-2 infection in New York. Ann Epidemiol. 2020;48:23-9.e4. Medline:32648546 doi:10.1016/j.annepidem.2020.06.004

70 Sami S, Akinbami LJ, Petersen LR, Crawley A, Lukacs SL, Weiss D, et al. Prevalence of SARS-CoV-2 Antibodies in First Responders and Public Safety Personnel, New York City, New York, USA, May-July 2020. Emerg Infect Dis. 2021;27:796-804. Medline:33493106 doi:10.3201/eid2703.204340

71 Van Dyke ME, Mendoza MCB, Li W, Parker EM, Belay B, Davis EM, et al. Racial and Ethnic Disparities in COVID-19 Incidence by Age, Sex, and Period Among Persons Aged <25 Years-16 US Jurisdictions, January 1-December 31, 2020. MMWR Morb Mortal Wkly Rep. 2021;70:382-8. Medline:33735165 doi:10.15585/mmwr.mm701le1

72 Ward H, Atchison C, Whitaker M, Ainslie KEC, Elliott J, Okell L, et al. SARS-CoV-2 antibody prevalence in England following the first peak of the pandemic. Nat Comm. 2021;12.

73 Weng CH, Saal A, McGuire DC, Chan PA. Persistently high SARS-CoV-2 positivity rate and incidence for Hispanic/Latinos during state reopening in an urban setting: a retrospective cohort study. Epidemiol Infect. 2021;149:e25. Medline:33455608 doi:10.1017/S0950268821000133

74 Werneck GL, Porto LC, Sena A, Ferreira OD, Cavalcanti AC, Santos AMG, et al. The incidence and geographical spread of SARSCoV-2 in Rio de Janeiro, Brazil based on RT-PCR test results. Rev Soc Bras Med Trop. 2021;54:e07792020. Medline:33605384 doi:10.1590/0037-8682-0779-2020

75 Yehia BR, Winegar A, Fogel R, Fakih M, Ottenbacher A, Jesser C, et al. Association of Race With Mortality Among Patients Hospitalized With Coronavirus Disease 2019 (COVID-19) at 92 US Hospitals. JAMA Netw Open. 2020;3:e2018039. Medline:32809033 doi:10.1001/jamanetworkopen.2020.18039

76 ICNARC. ICNARC report on COVID-19 in critical care - 10 April 2020. London: Intensive Care National Audit and Research Centre (ICNARC); 2020.

77 Stokes EK, Zambrano LD, Anderson KN, Marder EP, Raz KM, Felix SEB, et al. Coronavirus disease 2019 case surveillanceUnited States, January 22-May 30, 2020. MMWR Morb Mortal Wkly Rep. 2020;69:759-65. Medline:32555134 doi:10.15585/ mmwr.mm6924e2

78 Agarwal S, Schechter C, Southern W, Crandall JP, Tomer Y. Preadmission Diabetes-Specific Risk Factors for Mortality in Hospitalized Patients With Diabetes and Coronavirus Disease 2019. Diabetes Care. 2020;43:2339-44. Medline:32769128 doi:10.2337/dc20-1543

79 Alaa A, Qian ZZ, Rashbass J, Benger J, van der Schaar M. Retrospective cohort study of admission timing and mortality following COVID-19 infection in England. BMJ Open. 2020;10:e042712. Medline:33234660 doi:10.1136/bmjopen-2020-042712

80 Avula A, Nalleballe K, Toom S, Siddamreddy S, Gurala D, Katyal N, et al. Incidence of Thrombotic Events and Outcomes in COVID-19 Patients Admitted to Intensive Care Units. Cureus. 2020;12:e11079. Medline:33224673 
81 Castro VM, McCoy TH, Perlis RH. Laboratory Findings Associated With Severe Illness and Mortality Among Hospitalized Individuals With Coronavirus Disease 2019 in Eastern Massachusetts. JAMA Netw Open. 2020;3:e2023934. Medline:33125498 doi:10.1001/jamanetworkopen.2020.23934

82 Harrison SL, Fazio-Eynullayeva E, Lane DA, Underhill P, Lip GYH. Higher Mortality of Ischaemic Stroke Patients Hospitalized with COVID-19 Compared to Historical Controls. Cerebrovasc Dis. 2021;50:326-31. Medline:33774618 doi:10.1159/000514137

83 Hernandez-Romieu AC, Adelman MW, Hockstein MA, Robichaux CJ, Edwards JA, Fazio JC, et al. Timing of Intubation and Mortality Among Critically Ill Coronavirus Disease 2019 Patients: A Single-Center Cohort Study. Crit Care Med. 2020;48:e1045-53. Medline:32804790 doi:10.1097/CCM.0000000000004600

84 Imam Z, Odish F, Gill I, O'Connor D, Armstrong J, Vanood A, et al. Older age and comorbidity are independent mortality predictors in a large cohort of 1305 COVID-19 patients in Michigan, United States. J Intern Med. 2020;288:469-76. Medline:32498135 doi:10.1111/joim.13119

85 Kim L, Whitake M, O'Halloran A, Kambhampati A, Chai SJ, Reingold A, et al. Hospitalization Rates and Characteristics of Children Aged <18 Years Hospitalized with Laboratory-Confirmed COVID-19 - COVID-NET, 14 States, March 1-July 25, 2020. MMWR Morb Mortal Wkly Rep. 2020;69:1081-8. Medline:32790664 doi:10.15585/mmwr.mm6932e3

86 Xie J, Zu Y, Alkhatib A, Pham TT, Gill F, Jang A, et al. Metabolic Syndrome and COVID-19 Mortality Among Adult Black Patients in New Orleans. Diabetes Care. 2020;44:188-93. Medline:32843337 doi:10.2337/dc20-1714

87 Xie Y, Bowe B, Maddukuri G, Al-Aly Z. Comparative evaluation of clinical manifestations and risk of death in patients admitted to hospital with covid-19 and seasonal influenza: cohort study. BMJ. 2020;371:m4677. Medline:33323357 doi:10.1136/ bmj.m4677

88 Gold JAW, Wong KK, Szablewski CM, Patel PR, Rossow J, da Silva J, et al. Characteristics and Clinical Outcomes of Adult Patients Hospitalized with COVID-19 - Georgia, March 2020. MMWR Morb Mortal Wkly Rep. 2020;69:545-50. Medline:32379729 doi:10.15585/mmwr.mm6918e1

89 Abrams MP, Wan EY, Waase MP, Morrow JP, Dizon JM, Yarmohammadi H, et al. Clinical and cardiac characteristics of COVID-19 mortalities in a diverse New York City Cohort. J Cardiovasc Electrophysiol. 2020;31:3086-96. Medline:33022765 doi:10.1111/jce.14772

90 Ayoubkhani D, Nafilyan V, White C, Goldblatt P, Gaughan C, Blackwell L, et al. Ethnic-minority groups in England and Wales-factors associated with the size and timing of elevated COVID-19 mortality: a retrospective cohort study linking census and death records. Int J Epidemiol. 2021;49:1951-62. Medline:33349855 doi:10.1093/ije/dyaa208

91 Bassett MT, Chen JT, Krieger N. Variation in racial/ethnic disparities in COVID-19 mortality by age in the United States: A cross-sectional study. PLoS Med. 2020;17:e1003402. Medline:33539382 doi:10.1371/journal.pmed.1003402

92 Bixler D, Miller AD, Mattison CP, Taylor B, Komatsu K, Pompa XP, et al. SARS-CoV-2-Associated Deaths Among Persons Aged <21 Years - United States, February 12-July 31, 2020. MMWR Morb Mortal Wkly Rep. 2020;69:1324-9. Medline:32941417 doi:10.15585/mmwr.mm6937e4

93 Scannell Bryan M, Sun JH, Jagai J, Horton DE, Montgomery A, Sargis R, et al. Coronavirus disease 2019 (COVID-19) mortality and neighborhood characteristics in Chicago. Ann Epidemiol. 2021;56:47. Medline:33181262 doi:10.1016/j.annepidem.2020.10.011

94 Cowger TL, Davis BA, Etkins OS, Makofane K, Lawrence JA, Bassett MT, et al. Comparison of Weighted and Unweighted Population Data to Assess Inequities in Coronavirus Disease 2019 Deaths by Race/Ethnicity Reported by the US Centers for Disease Control and Prevention. JAMA Netw Open. 2020;3:e2016933. Medline:32721026 doi:10.1001/jamanetworkopen.2020.16933

95 de Lusignan S, Joy M, Oke J, McGagh D, Nicholson B, Sheppard J, et al. Disparities in the excess risk of mortality in the first wave of COVID-19: Cross sectional study of the English sentinel network. J Infect. 2020;81:785-92. Medline:32858068 doi:10.1016/j.jinf.2020.08.037

96 Elliott J, Bodinier B, Whitaker M, Delpierre C, Vermeulen R, Tzoulaki I, et al. COVID-19 mortality in the UK Biobank cohort: revisiting and evaluating risk factors. Eur J Epidemiol. 2021;36:299-309. Medline:33587202 doi:10.1007/s10654021-00722-y

97 Laurencin CT, Wu ZH, McClinton A, Grady JJ, Walker JM. Excess Deaths Among Blacks and Latinx Compared to Whites During Covid-19. J Racial Ethn Health Disparities. 2021;8:783-9. Medline:33751484 doi:10.1007/s40615-021-01010-x

98 Rushovich T, Boulicault M, Chen JRT, Danielsen AC, Tarrant A, Richardson SS, et al. Sex Disparities in COVID-19 Mortality Vary Across US Racial Groups. J Gen Intern Med. 2021;36:1696-701. Medline:33818679 doi:10.1007/s11606-021-06699-4

99 Credit K. Neighbourhood inequity: Exploring the factors underlying racial and ethnic disparities in COVID-19 testing and infection rates using ZIP code data in Chicago and New York. Regional Science Policy and Practice. 2020;12:1249-71. doi:10.1111/rsp3.12321

100 Scannell CA, Oronce CIA, Tsugawa Y. Association Between County-Level Racial and Ethnic Characteristics and COVID-19 Cases and Deaths in the USA. J Gen Intern Med. 2020;35:3126-8. Medline:32761284 doi:10.1007/s11606-020-06083-8

101 Yancy CW. COVID-19 and African Americans. JAMA. 2020;323:1891-2. Medline:32293639 doi:10.1001/jama.2020.6548

102 Rogers TN, Rogers CR, VanSant-Webb E, Gu LY, Yan B, Qeadan F. Racial Disparities in COVID-19 Mortality Among Essential Workers in the United States. World Med Health Policy. 2020;12:311-27. Medline:32837779 doi:10.1002/wmh3.358

103 Arasteh K. Prevalence of Comorbidities and Risks Associated with COVID-19 Among Black and Hispanic Populations in New York City: an Examination of the 2018 New York City Community Health Survey. J Racial Ethn Health Disparities. 2020. Online ahead of print. Medline:32794024 doi:10.1007/s40615-020-00844-1

104 Bailey ZD, Krieger N, Agénor M, Graves J, Linos N, Bassett MT. Structural racism and health inequities in the USA: evidence and interventions. Lancet. 2017;389:1453-63. Medline:28402827 doi:10.1016/S0140-6736(17)30569-X 
105 Krieger N. Discrimination and Health Inequities. Int J Health Serv. 2014;44:643-710. Medline:25626224 doi:10.2190/ HS.44.4.b

106 Paradies Y, Jehonathan B, Denson N, Amanuel E, Priest N, Pieterse A, et al. Racism as a Determinant of Health: A Systematic Review and Meta-Analysis. PLoS One. 2015;10:e0138511. Medline:26398658 doi:10.1371/journal.pone.0138511

107 Pettit NN, MacKenzie EL, Ridgway JP, Pursell K, Ash D, Patel B, et al. Obesity is Associated with Increased Risk for Mortality Among Hospitalized Patients with COVID-19. Obesity (Silver Spring). 2020;28:1806-10. Medline:32589784 doi:10.1002/ oby. 22941

108 McGonagle D, Plein S, O’Donnell JS, Sharif K, Bridgewood C. Increased cardiovascular mortality in African Americans with COVID-19. Lancet Respir Med. 2020;8:649-51. Medline:32473125 doi:10.1016/S2213-2600(20)30244-7

109 Nguyen Y, Corre F, Honsel V, Curac S, Zarrouk V, Burtz CP, et al. A nomogram to predict the risk of unfavourable outcome in COVID-19: a retrospective cohort of 279 hospitalized patients in Paris area. Ann Med. 2020;52:367-75. Medline:32723107 doi:10.1080/07853890.2020.1803499

110 Lian J, Jin X, Hao S, Cai H, Zhang S, Zheng L, et al. Analysis of Epidemiological and Clinical Features in Older Patients With Coronavirus Disease 2019 (COVID-19) Outside Wuhan. Clin Infect Dis. 2020;71:740-7. Medline:32211844 doi:10.1093/ $\mathrm{cid} / \mathrm{ciaa2} 42$

111 CDC COVID Response Team. Severe Outcomes Among Patients with Coronavirus Disease 2019 (COVID-19)-United States, February 12-March 16, 2020. MMWR Morb Mortal Wkly Rep. 2020;69:343-6. Medline:32214079 doi:10.15585/mmwr. mm6912e2

112 Strickland OL, Powell Young Y, Reyes-Miranda C, Alzaghari O, Brannon C, Newman Giger J. African-Americans Have a Higher Propensity for Death from COVID-19: Rationale and Causation. J Natl Black Nurses Assoc. 2020;31:1-12. Medline:32853490

113 El Chaar M, King K, Lima AG. Are black and Hispanic persons disproportionately affected by COVID-19 because of higher obesity rates? Surg Obes Relat Dis. 2020;16:1096-9. Medline:32522406 doi:10.1016/j.soard.2020.04.038

114 Peate I. Why are more BAME people dying from COVID-19? Br J Nurs. 2020;29:545. Medline:32463744 doi:10.12968/ bjon.2020.29.10.545

115 Merrifield N. How Covid-19 exposed existing ethnic inequalities: Socioeconomic factors and discrimination - and not simply genetics - may be behind higher death rates of non-white people, including GPs. Pulse. 2020. Available: https://www.pulsetoday.co.uk/analysis/workforce/how-covid-19-exposed-existing-ethnic-inequalities-including-for-gps/. Accessed: 1 June 2021.

116 Ferdinand KC, Nasser SA. African-American COVID-19 Mortality A Sentinel Event. J Am Coll Cardiol. 2020;75:2746-8. Medline:32330545 doi:10.1016/j.jacc.2020.04.040

117 Abuelgasim E, Saw LJ, Shirke M, Zeinah M, Harky A. COVID-19: Unique public health issues facing Black, Asian and minority ethnic communities. Curr Probl Cardiol. 2020;45:100621. Medline:32448759 doi:10.1016/j.cpcardiol.2020.100621

118 Sallis JF, Glanz K. The Role of Built Environments in Physical Activity, Eating, and Obesity in Childhood. Future Child. 2006;16:89-108. Medline:16532660 doi:10.1353/foc.2006.0009

119 Walters A. Inequities in access to education: Lessons from the COVID-19 pandemic. Brown Univ Child Adolesc Behav Lett. 2020;36:8. doi:10.1002/cbl.30483

120 Yaya S, Yeboah H, Charles CH, Otu A, Labonte R. Ethnic and racial disparities in COVID-19-related deaths: counting the trees, hiding the forest. BMJ Glob Health. 2020;5:e002913. Medline:32513864 doi:10.1136/bmjgh-2020-002913 